\title{
Study of the Process of Alloying Steel By Nitrated Chromium
}

\section{Leonid Andreevich Smirnov, Oleg Vadimovich Zayakin", Vladimir Ivanovich Zhuchkov ${ }^{1}$, Alexey Sergeevich Oryshchenko ${ }^{2}$, and Grigoriy Yurievich Kalinin ${ }^{2}$}

${ }^{1}$ Institute of Metallurgy UrD RAS, Ekaterinburg, Russia

${ }^{2}$ CRISM Prometey of NRC Kurchatov Institute, St. Petersburg, Russia

\section{Abstract}

Experimental investigation of process of steel alloying by nitrated chromium was carried out. As raw material for metal-melt treatment, the steel containing $20.3 \% \mathrm{Cr}$; $11.2 \% \mathrm{Mn} ; 7.1 \% \mathrm{Ni} ; 1.46 \% \mathrm{Mo} ; 0.33 \% \mathrm{Si}$; and $0.05 \% \mathrm{C}$ was used. As-cast samples of nitrated chromium ( $\Phi \mathrm{XH} 10$ and $\Phi \mathrm{XH} 20$ grades) were used as alloying additives. The compositions of grades are $85.7 \% \mathrm{Cr} ; 8.0 \% \mathrm{~N}$, and $73.9 \% \mathrm{Cr} ; 16.1 \% \mathrm{~N}$, respectively. Experiments were carried out in high-temperature laboratory unit at $1500^{\circ} \mathrm{C}$. It was found that the degree of nitrogen transfer into steel reaches up to $84 \%$ at the application

Corresponding Author: Oleg Vadimovich Zayakin zferro@mail.ru

Received: 5 February 2019 Accepted: 6 March 2019 Published: 17 March 2019

Publishing services provided by Knowledge E

(c) Leonid Andreevich Smirnov et al. This article is distributed under the terms of the ons Attribution License, which permits unrestricted use and redistribution provided that the original author and source are credited.

Selection and Peer-review under the responsibility of the NIOKR-2018 Conference Committee.

\section{G OPEN ACCESS} of as-cast specimen of nitrated chromium containing $8 \%$ of nitrogen and 1 min exposure time after addition to ferroalloy. Further high-temperature soaking of nitrated steel causes a dropdown of nitrogen concentration due to thermal dissociation of existed nitrogen-containing compounds in the melt and exhalation in gas phase. This prevents nitrogen transfer into the steel. It was demonstrated a possibility in principle of obtaining of chrome-manganese steel containing about $0.4-0.6 \%$ of nitrogen at melt alloying by nitrated chromium in air atmosphere at exposure time up to $15 \mathrm{~min}$.

Keywords: metallurgy, nitrogen, chromium, steel, digestion degree, physicochemical characteristics

\section{Introduction}

Nitration of steels enables one to decrease its prime cost due to lower consumption of costly ferroalloys and improve functional properties of steel products. Addition of nitrogen leads to improvement of strength, ductility, and corrosion-resistance of austenite steels [1]. Currently, nitrogen doping is used in the preparation of various grades of general purpose steels - from stainless to low-alloyed [2-9] and micro-alloyed for construction and engineering [10-12]. Nitrated ferroalloys are used for the production of steels with high content of nitrogen. Alloying by nitrogen enables one to decrease a content of nickel and manganese in steels. The price of alloying elements has a significant impact on the prime cost of corrosion-resistant steels grades. Well-known grades of nitrated ferroalloys FeMn80C05N2 (1.5-2.5\% N), FeMn70C10N5 (4-8\% N), ФXH100ФXH600 (1-6\% N) and new ones with increased nitrogen content (ФXH10, ФXH20 8-20\% N, respectively), as well as Nitrovan12 and Nitrovan16 [16] are used in state-of-the- 
art conditions of steel making. For efficient application of new ferroalloys compositions the knowledge of their functional characteristics [16-18] and features of steel alloying processes proceeding [19-20] are highly demanded.

In the present work the nitrated chromium (ФXH10, $Ф$ XH20 grades) were chosen as the samples for studying of steel nitration process. Chemical composition of initial samples is listed in the Table. $\Phi \mathrm{XH} 10$ and $\Phi \mathrm{XH} 20$ specimens were obtained by melting and sintering, respectively. The steel $(04 \mathrm{X} 2 \mathrm{OH} 6 Г 11 \mathrm{M} 2 \mathrm{~A} Ф \mathrm{5}$ grade) was used for treatment as metal melt.

TABLE 1: Chemical composition of initial samples.

\begin{tabular}{|c|c|c|c|c|c|c|c|}
\hline \multirow[t]{2}{*}{ Sample } & \multicolumn{7}{|c|}{ Chemical Concentration*, \% } \\
\hline & C & $\mathrm{Cr}$ & $\mathrm{Mn}$ & $P$ & $\mathrm{~S}$ & Al & $\mathrm{Si}$ \\
\hline Ferroalloy ФХH10 & 0.21 & 85.7 & - & 0.007 & 0.011 & 0.11 & 4.02 \\
\hline Ferroalloy $Ф$ ХH2O & 0.13 & 73.9 & - & no data & 0.015 & 0.55 & 0.35 \\
\hline $\begin{array}{l}\text { Steel } \\
\text { 04X2OH6Г11М2АФБ }\end{array}$ & 0.05 & 20.3 & 11.2 & 0.014 & 0.006 & - & 0.33 \\
\hline Sample & $\mathrm{N}$ & $\mathrm{Ni}$ & Mo & V & $\mathrm{Nb}$ & & \\
\hline Ferroalloy ФХН10 & 8.00 & - & - & - & - & & \\
\hline Ferroalloy $Ф$ ХH2O & 16.05 & - & - & - & - & & \\
\hline $\begin{array}{l}\text { Steel } \\
04 X 20 H 6 Г 11 \mathrm{M} 2 А Ф Б\end{array}$ & 0.05 & 7.1 & 1.46 & 0.19 & 0.15 & & \\
\hline
\end{tabular}

Studying of process characteristics of steel alloying by nitrated chromium was carried out in laboratory conditions using Tamman furnace with protecting cover in air. Experiments were carried out at temperature $1500{ }^{\circ} \mathrm{C}$. Nitrated chromium was added to the steel melt and exposure of the melt was up to $30 \mathrm{~min}$, during this period sampling was carried out. The added quantity of nitrated chromium was made according to calculated value of nitrogen to obtain its $1 \%$ concentration. At the stage of ferroalloy addition there were the two processes 1) nitration and 2) alloying by appropriate elements. Chromium content was increased in the steel up to 28.5 and $24.7 \%$ at application of $Ф$ XH10 and $\Phi \mathrm{XH} 20$, respectively, and it was nearly constant during exposure time.

Kinetic curves of nitrogen content in steel with exposure time are presented in Figure 1. Relationship between exposure time and nitrogen transfer degree is shown in Figure 2.

The result obtained using as-cast sample of nitrated chromium $(8 \% N)$ is by far the best concerning nitrogen content and its transfer degree. At temperature $1500{ }^{\circ} \mathrm{C}$ and exposure time $1 \mathrm{~min}$ after alloying the digestion degree was 84\% (at nitrogen content in steel $0.84 \%$ ), while exposure time was $30 \mathrm{~min}$ the digestion degree became only $52 \%$ 
( $\mathrm{N}$ concentration in steel 0.52 ). It is necessary to note that the sharp drop of nitrogen content from 0.84 to 0.62 was during first period of exposure ( $5 \mathrm{~min}$ ). Three kinetic regions of nitrogen behavior may be marked out at the curves (Figure 1). First, nitrogen absorption by the melt; second, nitrogen desorption with high rate; third, low rate desorption (approaching of equilibrium state). The values of nitrogen concentration in steel in first minutes after alloying is above equilibrium one. There is the explanation of further decrease of nitrogen content during $30 \mathrm{~min}$ exposure. The short-term high nitrogen content in the steel can be explained by the form of its entry into the melt. $\mathrm{X}$ ray diffraction analysis of ferroalloys revealed that $\Phi$ XH1O sample consists of $\sim 80 \% \mathrm{Cr}_{2} \mathrm{~N}$ and $\sim 20 \%$ solid solution of iron in chromium. As for $\Phi X H 20$ alloy, there was detected two types of chromium nitrides $\mathrm{CrN}$ and $(\mathrm{CrFe})_{2} \mathrm{~N}$, their ratio (between each other) was about 4:1. Nitrogen releases in gaseous phase from nitrated steel samples at high-temperature exposure due to thermal dissociation of nitrogen-containing compounds. Besides, the higher content of nitrogen in steel is, the higher intensity of its release.

The nitrogen digestion degree is strongly dependent on properties of chromium, manganese and other elements nitrides formed in the steel, temperature, and characteristics of used alloys: type of nitrogen compounds in nitrated ferroalloy and alloy microstructure (density, porosity). True and apparent density of ferroalloys under investigation was measured by picnometric technique. It was found that an increase of nitrogen content in ferrochrome (in the considered range) leads to decrease of its true density. This enables one to obtain alloys characterized by optimal values of density $6200-6700$ $\mathrm{kg} / \mathrm{m}^{3}$. However, they have very low apparent density values due to very high porosity of nitrated ferroalloys: $\Phi X H 10-4170 \mathrm{~kg} / \mathrm{m}^{3}$ and $\Phi X \mathrm{H} 20-3540 \mathrm{~kg} / \mathrm{m}^{3}$. Due to the lower density, the $\Phi \mathrm{XH} 20$ alloy can more melt on the surface of the steel melt and is characterized by a lower degree of nitrogen absorption into the steel compared to the more dense $\Phi \times H 10$ alloy. It seems logical to conclude that $\Phi \times H 20$ alloy with lower density will be more melted at the surface of steel melt.

It seems that the higher nitrogen digestion degree at application of $\Phi \mathrm{XH} 10$ is due to alloy cast structure (higher density) and the lowest nitrogen content on the chromium unit (N/Cr in the alloy is 0.09 ), while the $\mathrm{N} / \mathrm{C}$ ratio is 0.22 in $\Phi \mathrm{XH} 20$ alloy.

Obtained experimental data concerning nitrogen transfer degree (38-55\%) from the ferroalloys under investigation into steel at $15 \mathrm{~min}$. exposure time corresponds to the literature data. In the research [21] it was demonstrated that at steel alloying by nitrated vanadium and ferromanganese with $4-8 \% \mathrm{~N}$ in a bucket, the nitrogen digestion degree is $55-65$ and $20-35 \%$, respectively. 


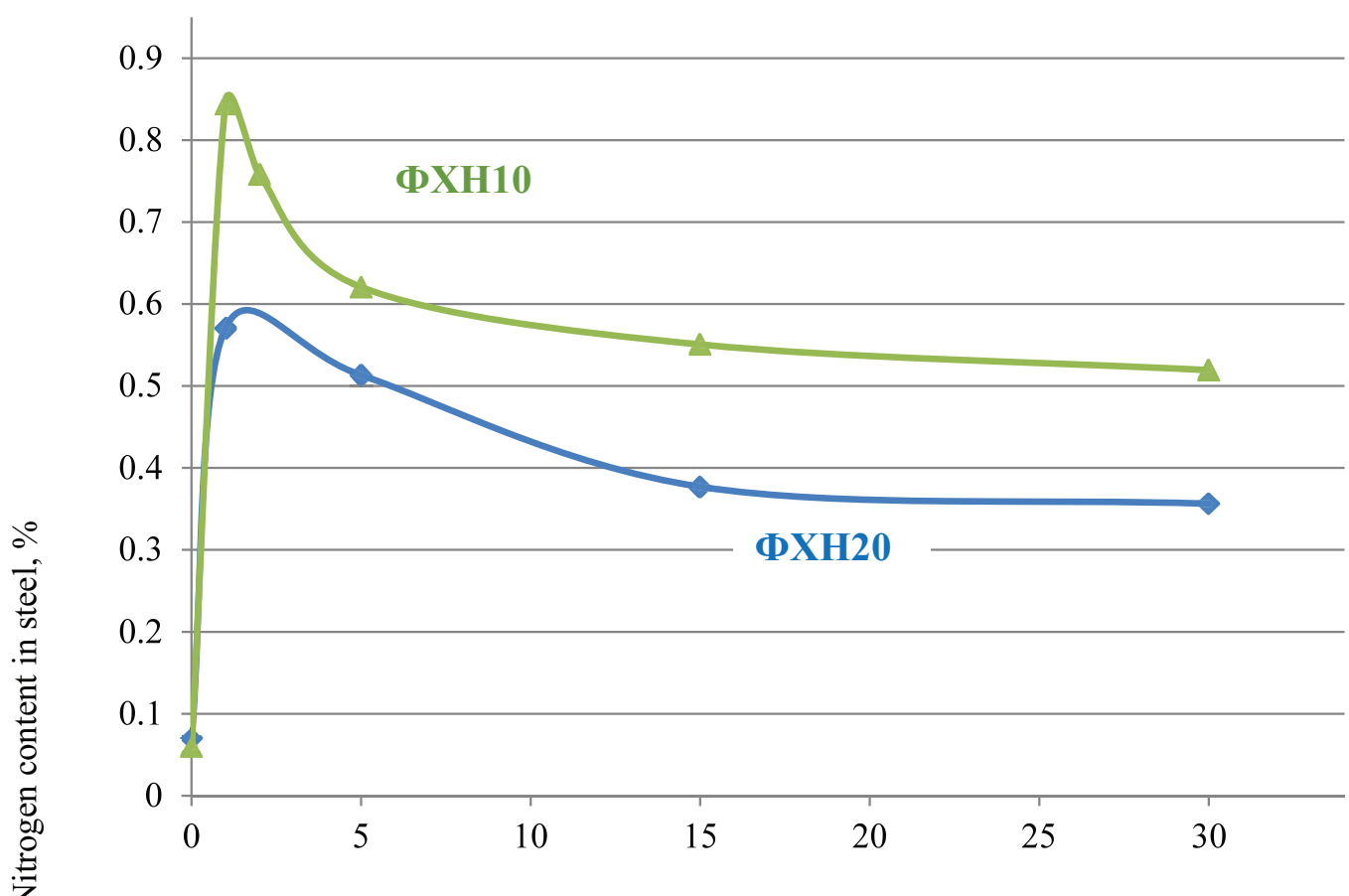

Exposure time, min

Figure 1: Time-temperature dependence of nitrogen content in steel at alloying by nitrated chromium at $1500^{\circ} \mathrm{C}$.

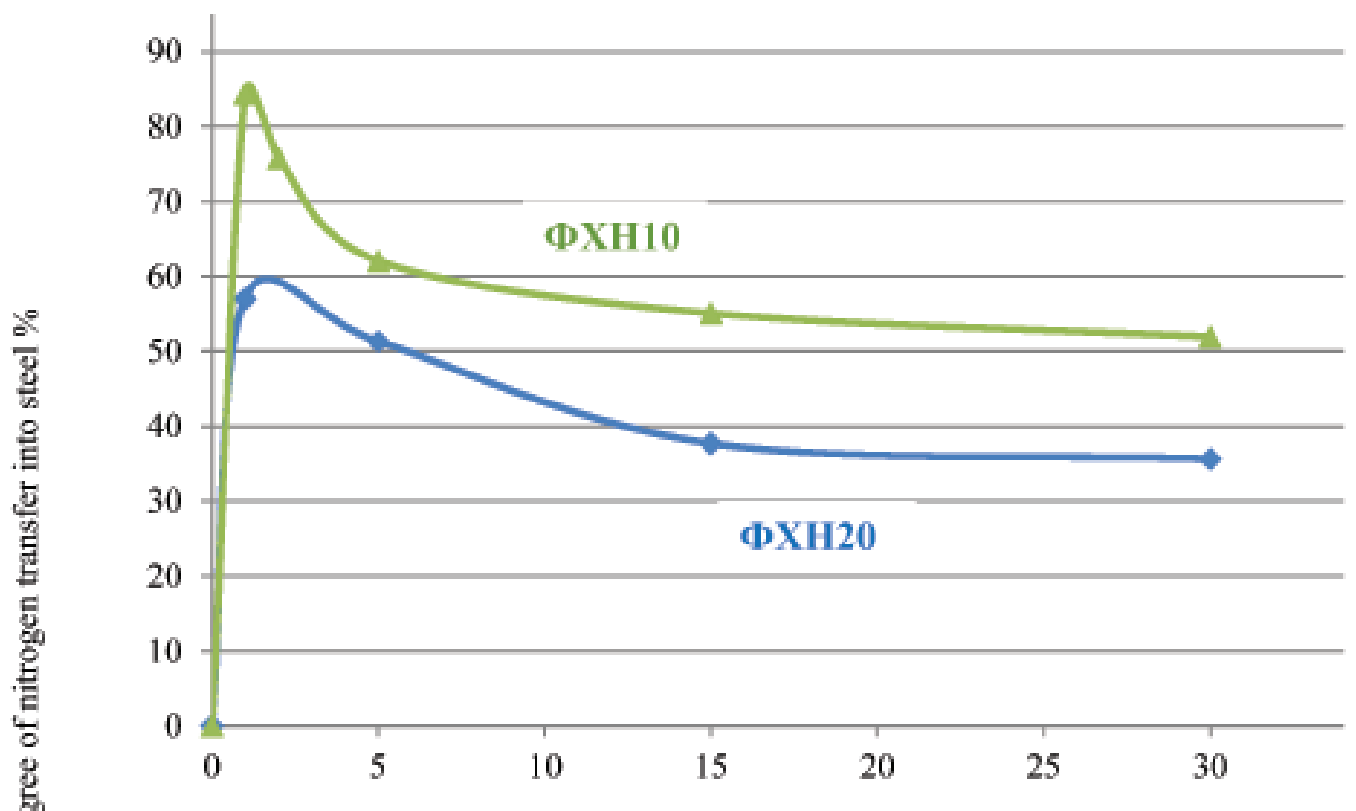

Exposure time, min

Figure 2: Time-temperature dependence of degree of nitrogen transfer in steel at alloying by nitrated chromium at $1500^{\circ} \mathrm{C}$. 


\section{Conclusions}

1. The experimental time-temperature dependence of nitrogen distribution at alloying of steel (04X2OH6Г11M2АФБ grade) by as-cast $Ф$ XH10 and sintered $Ф$ XH2O ferrochromium was studied at 30 min exposure time in light-oxidizing atmosphere at $1500^{\circ} \mathrm{C}$.

2. It was found that the highest transfer degree of nitrogen in steel is $84 \%$. It was detected at application of as-cast nitrated chromium sample having $8 \%$ of nitrogen and short exposure time (1 $\mathrm{min}$ ) after ferroalloy addition. Further high-temperature soaking of nitrated steel causes a drop down of nitrogen concentration due to thermal dissociation of existed in the melt nitrogen-containing compounds and exhalation in gas phase. This prevents nitrogen transfer into the steel.

3. It was demonstrated a possibility in principle of obtaining of chrome-manganese steel containing $-0.4-0.6 \%$ of nitrogen at melt alloying by nitrated chromium in air atmosphere at exposure time up to $15 \mathrm{~min}$.

\section{Funding}

The work was supported within the framework of the State Task.

\section{References}

[1] Savray, R.A. Makarov A.V., Gorkunov E.S., et al. (2015) Mechanical characteristics of nitrous austenite steel $(04 \mathrm{X} 20 \mathrm{H} 6 \Gamma 11 \mathrm{M} 2 \mathrm{~A} \Phi \mathrm{B}$ grade) at static extension within the temperature range from -70 to $+140{ }^{\circ} \mathrm{C}$. Vector nauki TGU, Vol.34, no. 4, pp. 100-107

[2] Bannykh, O.A. (2005). Cost-saving nitrous stainless steels as promising substitutor of light-weight alloys. Metal Science and Heat Treatment, no. 7. pp. 9-13.

[3] Gavriljuk, V.G. and Berns H. (1999). High nitrogen steel: structure, properties, manufacture, Berlin: Springer.

[4] Kostina, M.V. (2003). Development of Cr-N steel alloying principles and corrosionresistant steels of new generation having structure of nitrous martensite and austenite for heavy loaded units in modern machines. Doctor Thesis. IMET RAS.

[5] Gorynin, I.V., Rybin, V.V, Malyshevskiy, V.A. et al. (2005). Development of a brand new promising corrosion-resistant hull plates alloyed by nitrogen. Material science problems, no. 2. pp. 40-54. 
[6] Kalinin, G.Y., Mushnikova, S.Yu., Nesterova, E.V., el at., (2006) Study of structure and properties of high-strength corrosion-resistant nitrous steel of $04 \mathrm{X} 20 \mathrm{H} 6 \Gamma 11 \mathrm{M} 2 \mathrm{AФБ}$ grade. Material science problems. no. 1. pp. 45-53.

[7] Baeva, L.A., Ilyichev, M.V., Tyuftyaev, A.S., et al. (2017). Nitrogen influence at plasma-arc remelting on structure, mechanical properties and corrosion-resistance of stainless steels. Steel, no. 12., pp. 54-56.

[8] Rashev, C.V. (1995). Highly nitrated steels Metallurgy under pressure. Sofia: Publishing house of Bulgarian Science Academy "Prof. Marin Drinov".

[10] Nakamura, N., Tsuchiyma, T. and Takaki, S. (1998). Effect of structural factors of the mechanical properties of the high nitrogen austenitic steels, in Book of Abstracts of 5-th Int. Conf. High Nitrogen Steels. HNS-98. Espoo Finland - Stockholm Sweden.

[10] Odesskii, P.D., Smirnov, L.A., Parshin, V.A. et al. (2015). Nitrogen as a microalloying element in steel for metallic structures. Steel in Translation, vol. 45, no. 5, pp. 378379.

[11] Panfilova, L.M. and Smirnov, L.A. (2015). Microalloying of manufacturing steel with vanadium and nitrogen. Steel in Translation, vol. 45, no. 11, pp. 887-893.

[12] Panfilova, L.M. and Smirnov, L.A. (2015). Effect of structural factors and nitride strengthening phases on new generafion steel rolled product structural strength. Metallurgist. 2015. vol. 58. no. 5. pp. 396-400.

[13] Zhuchkov, V.I., Leontiev, L.I., Selivanov, E.N., et al. (2014). Prospects of stainless steel production with application of domestic chromium and nickel ferroalloys, in Proceedings of Conference Modern trends in the field of theory and practice of extraction and recycling of mineral and technogenic raw. Ekaterinburg: USTU-UPI.

[14] Khalezov B.D., Zayakin, O.V., Gavrilov, A.C., et al. (2017). Hydro- pyrometallurgical method of Fe-Ni-Cr-Mn-Si system alloys obtaining. Butlerov communications, vol. 52, no. 10, pp. 111-117.

[15] Shatokhin, I.M., Zaitdinov, M.Kh., Bigeev V.A., et al. (2012). Application of SHS technology in metallurgy. Magnitogorsk: Magnitogorsk State Technical University named after G.I. Nosov.

[16] Zhuchkov, V.I., Zayakin, O.V. and Malcev, Y.B. (2001). Melting temperatures and density of nickel-containing ferroalloys. Melts, no. 1, pp. 7-9.

[17] Zhuchkov, V.I., Andreev, N.A., Zayakin, O.V., et al. (2013). Composition and performance of chromium-bearing ferroalloys. Steel in Translation, vol. 43, no. 5, pp. 306308.

[18] Andreev, N.A., Zhuchkov, V.I., Zayakin, O.V. (2013). Density of chromium-containing ferroalloys. Russian Metallurgy (Metally), no. 6, pp. 418-419. 
[19] Zayakin, O.V., Zhuchkov, V.I., and Lozovaya, E.Yu. (2007). Melting Time of NickelBearing Ferroalloys in Steel. Steel in Translation, vol. 37, no. 5, pp. 416-418.

[20] Zhuchkov, V.I., Zayakin, O.V, Lozovaya, E.Yu., et al. (2016). Study of melting process of $\mathrm{Fe}-\mathrm{Ni}$ - $\mathrm{Cr}$ alloys in iron-carbon melt. Butlerov communications, vol. 47, no. 8, pp. $56-62$.

[21] Lyakishev, N.P. and Gasik, M.I. (1999). Theory and technology of ferroalloys electrometallurgy. Moscow: Eliz. 